\title{
A Comparative Study of Chemistry Students' Learning Styles Preferences in Selected Public and Private Schools in Lagos Metropolis
}

\author{
Dr.Oluwatomi M. Alade ${ }^{1}$ and Mrs Angela C. Ogbo ${ }^{2}$ \\ ${ }^{2}$ Box 183, University of Lagos Post Office, Department of Educational Foundations, Faculty of Education, \\ University of Lagos, Akoka-Yaba, Lagos, Nigeria. \\ ${ }^{I}$ Department of Educational Foundations, Faculty of Education, University of Lagos, Akoka-Yaba, Lagos, \\ Nigeria.
}

\begin{abstract}
This study investigated the learning style preferences of chemistry students in both public and private secondary schools in Lagos metropolis, Nigeria. Descriptive research survey design was adopted for this study. The sample consisted of two hundred (200) SS 2 Chemistry students. The participants were selected using hat and draw and disproportionate stratified sampling methods. Instruments used to collect data were the Chemistry Achievement Test (CAT) and the VAK Learning style Test (VLST). The reliability measures of CAT and VLST were 0.66 and 0.70 respectively. Four research questions and corresponding hypotheses were tested at 0.05 level of significance. Data collected were analysed using Chi-square statistics. The result showed that there is a significant relationship between learning style preferences of students and their performance in the chemistry achievement test in both public and private schools. Visual learning style was the predominant preference among students in both school types. The researcher recommends that chemistry teachers should use a variety of teaching styles to accommodate the various learning styles of their students. An alignment between teaching and learning styles will improve the teaching, learning and performance of students in Chemistry.
\end{abstract}

Keywords: Learning Style Preferences, Teaching style, Performance, Chemistry, Public, Private Schools, Lagos.

\section{Introduction}

Lagos is the commercial nerve centre of Nigeria. It is a nodal centre characterized by hustle and bustle, wealth and poverty. There are numerous secondary schools in Lagos State both 'approved' and 'unapproved'. The private schools are the non-state providers of education. They are run by individuals, faith-based groups, charity organizations and communities. Their sources of funding range from school fees alone to grants-in-aid (mainly mission schools) from research agencies. These private schools have complete autonomy as regards management, pedagogy and hiring. We also have elite private schools and the very low fee paying ones. Public schools are the government schools. They are owned, funded, run and managed by the government with very little or no autonomy at the school level. Government schools are assumed to be approved regardless of standards. Operating a private school in Lagos without approval is illegal. Also, running a private school for the purpose of making profit is against government regulations (Education Sector Support Programme in Nigeria ESSPIN, 2011). Certain private schools attain the approved school status without fulfilling the guidelines (Tooley, Dixon and Olaniyan, 2005; ESSPIN 2011). Students do not pay school fees in government schools. A study carried out by the Department for International Development (DFID) Education Sector Support Programme in Nigeria (ESSPIN) in 2011, revealed that the private schools outnumber the public schools. This study asserted that there were twelve thousand and ninety-eight (12 098) private schools and six hundred and thirty-nine (639) public schools in Lagos State. ESSPIN also conducted a Monitoring Learning Achievement exercise in which public and private schools students participated and it was found that the private school children performed better. One then wonders what it is that makes the private schools tick. Studies on poor academic performance revealed that aside from school-related characteristics/factors, the students' personal characteristics (especially learning styles preferences) can also adversely affect a students' achievement. They also pointed out that school-related characteristics/factors had greater impact on students' academic performance than the students' personal characteristics.

There are some observable school characteristics that may be common to both private and public schools. Some of them include: large class-size, inadequate teaching resources, physical appearance, small classroom space, location of school, co-curricular activities, shortage of teachers, frequent changes of teachers and teachers' attitude to work, sub-standard teachers and poor instructional strategies (ESSPIN,2011). The extent to which these factors are present or absent in public and private schools determines the quality of instruction their students receive, characteristics of these students and hence their academic performance. This 
research work seeks to investigate students' characteristics (learning styles preferences) in the two school types and how these students' characteristics affect their academic performance.

In the teaching-learning environment there have been questions as to why some students learn better than other students under the same conditions. Educators are concerned about using different teaching methods and instructional materials to improve achievement of their students. Students on the other hand, have a role to play in improving their performance after a given period of instruction. If the teacher does all that is in his power to do to ensure good performance and the students do not play their part; then success may not be achieved. Berg (2005), identified attitude, motivation and genuine interest as the most important student characteristics associated with successful learning. There would be no meaningful success if the students do not exhibit these characteristics in the learning environment.

Yeung, Read and Schmid (2005), posit that several factors influence student learning. Examples of such factors include but are not limited to students learning style preferences, interest in the materials being studied and the learning environment. They went on to say that an individual's learning style preference deals with the way the person responds to stimuli in the learning context and the characteristic way he acquires and uses information. Since students learn in different ways, there is need for the students' learning style preferences to align with the instructors teaching style for good performance. The most effective teacher is one who caters for a range of learning styles. There is obvious need to incorporate the students' learning style into the instructional and assessment procedures. This study sets out to investigate and compare the learning style preferences of students in public and private schools in Lagos Metropolis. The relationship between students' learning styles and their academic performance will also be reported.

Learning style was defined by Dunn and Dunn (1992), as the way each learner begins to concentrate on, process and remember new and difficult information. When an individual's multidimensional characteristics are examined the person's learning style can be identified. An individual's learning style is the way the person begins to process, internalize and concentrate on a new material (Gremli, 1996).

Learning according to Sara 2010, can be defined as the summation of a person's life experiences which have survival value for him and which is relatively permanent. Learning can equally be classified as conscious or unconscious. Conscious learning occurs when a person learns deliberately while the unconscious learning is when learning is without deliberate effort.

Individuals exhibit different approaches to solving a problem. Some are systematic, others are haphazard. The approach of an immature person gradually transforms into a pattern of behaviour called learning style. Sara 2010, made a distinction between style and strategy. Learning Style is the characteristic way a person thinks or approaches a problem while learning strategy is a particular approach used to solve a narrower range of problems. Learning style of a person is stable over the years but learning strategy varies with the situation under consideration.

According to Spoon and Schel (1998), Neil Fleming's VAK/VARK model categorized learning style into three categories, namely: visual learners; auditory learners and kinaesthetic or tactile learners. Fleming was of the opinion that visual learners have preference for seeing (think in pictures, visual aids like diagrams, overhead slides and hand outs). Auditory learners learn by listening to lectures, discussions, tapes, e.tc. Tactile/kinaesthetic learners have learning preference for experience -moving, touching and doing (active exploration of the world, science projects and experiments, e.t.c). Using the Fleming's Model in pedagogy allows the tutor to prepare lessons that address these areas. This model enables the student to identify his learning preferences and use them to improve performance.

Felder and Soloman (2005), cited in Apanpa and Ogunbiyi (2012) categorized the learning style and strategies as shown below:
* Active and reflective learners
* Sensing and Intuitive learners
* Visual and verbal learners
* Sequential and Global learners

\subsection{Active and Reflective Learners}

Active learners retain and understand best by doing something active with what they learn. That is by discussing or explaining it to another person. Reflective learners prefer to think quietly about what they have learnt first.

Active learners tend to like group work more than reflective learners. Reflective learners prefer to work alone. Sitting through lecture without doing anything physical is hard for both active and reflective learners but even harder for active learners. 


\subsection{Sensing and Intuitive Learners}

Sensory learners like learning facts. Intuitive learners prefer discovering possibilities and relationships. Sensory learners learn by well-established methods. They dislike complications and surprises; they like innovation and dislike repetition. Sensors will resent being tested on materials not explicitly covered in class. Sensors are patient with details and good at memorising facts and doing hands-on laboratory work. Intuitive learners are good at grasping new concepts and more comfortable than sensors with abstractions and mathematical formulations. Sensory learners tend to be more practical and careful than intuitive learners. Intuitive learners tend to work faster and tend to be more innovative than sensory learners.

\subsection{Verbal and Visual Learners}

Visual learners remember best what they see. For instance: pictures diagrams, flow charts, time lines, films and demonstrations. Verbal learners learn better from words written and spoken explanations. Everyone learns more when information is presented both visually and verbally.

\subsection{Sequential and Global Learners}

Sequential learners gain understanding in linear step, when each step follows the previous step logically. Global learners learn in large lumps, absorbing materials randomly without seeing connections. Then they suddenly understand. Sequential learners follow logical stepwise procedures in finding solutions. Global learners are able to solve complex problems quickly. They put things together in new ways once they have grasped the big picture. They may have difficulty explaining how they did it.

Chemistry is the basis of all environmental sciences. All science students must offer and pass it at credit level before they can proceed to study any science course at the university level (Kolawole et al, 2011). Some factors were identified by Adeyemi (2011), as causes of students' academic failure. They are: lack of personal confidence, emotional instability and temperamental tendency towards extroversion. Al-methen and Wilkinson (1992) argued that students' failures are due to academic problems arising from personal inadequacies like: low ability, negative self-concept, anxiety, peer influence, poor classroom conditions and lack of home support. This study is concerned with investigating student characteristics (learning style preferences) that are prevalent in public and private schools in Lagos State and the extent to which these features are related to students' performance. The researcher will consider, learning styles and academic performance in the two school types.

Even though there are similarities in the way people learn, each person learns in a unique way which is as individualistic as a finger-print (Gremli, 1996). In his Theory regarding the nature of intelligence, Howard Gardner (1993), outlined the following as the characteristics of student learning that teachers have to take into consideration in order to help their students learn: verbal/linguistic intelligence; logical/mathematical intelligence; visual/spatial intelligence; bodily/kinaesthetic intelligence; musical/rhythmic intelligence; interpersonal intelligence; intrapersonal intelligence; and naturalistic intelligence. A verbal linguistic intelligent student asks lots of question, enjoys talking, has good vocabulary, enjoys reading, enjoys playing with words, likes to write, etc. A logical or Mathematical intelligent student enjoys solving puzzles, plays with numbers, is oriented to rule based activities, is interested in logic, wants to know how things work, and does well in Mathematics, reasoning, logic and problem solving. A visual/spatial intelligent person likes to draw, likes to take things apart, likes to build things, is mechanically adept, remembers places by description or images, can interpret maps. A bodily/kinaesthetic intelligent student is good at physical activities (e.g. sports, acting, dance and crafts), has a good sense of balance and rhythm, can communicate ideas through gesture. (Intime, 2001). Learning style can be seen as the way an individual learns, understands and digests a piece of information in a learning environment.

If a teacher knows his students' learning style (even basic information), it helps the teacher to help the students. It will also help the teacher to prepare the students to help themselves; since students have to learn the best strategies to improve their own learning (metacognition). By encouraging students to take responsibility for their own learning, the teacher increases their chances for success in that subject and others (Felder, 2003). The following five dimensions to learning styles were identified by Felder, 1993. They include:

- Perception(sensory or intuitive)

- Input modality (visual-nonverbal, auditory, or tactile-kinaesthetic)

- Organization (inductive or deductive)

- Processing (active or reflective)

- Understanding (sequential or global)

He said that students do not fall cleanly into one category but have different learning styles or preferences in different situations.

Felder emphasized that instructors should note that many students may not know their learning preferences. Hence it is important for the students to practice metacognition or learning how one learns. This 
allows the students to take responsibility for their own learning success by adopting appropriate learning strategies based on their preferences (Felder, 1993).

Many people who learnt chemistry did so by lecture method. The teaching style used by $89 \%$ of science professors is lecture method (Timberlake, 2001). During lecture, students are not actively involved in the lesson; their attention span is short and their retention of the concepts taught is minimal. Don Paulson (1998), reported that the use of active-learning approach produced an average retention rate of $78 \%$ as opposed to $38 \%$ when he used lecture method. In a student-centred class, students are encouraged to participate actively rather than being passive. Students are involved in the class through a variety of hands-on-activities (Timberlake, 2001). She called these activities lecturePLUS; where P denotes participation; L stands for learning, $\mathrm{U}$ denotes understanding and $\mathrm{S}$ for success. These activities entail group homework projects, peer presentations, in-class collaborative learning, on-going assessments and mini-lectures using PowerPoint.

Adesoji and Ibraheem (2009) were of the view that mathematical abilities of students were tied to their success in chemistry. They reiterated that the ability to manipulate symbols (geometry) and the ability to use and manoeuvre algebraic symbols to solve problems were necessary for success in chemistry. They went on to say that students with intellectual abilities had greater chance of success in chemistry than those without intellectual abilities.

Many factors influence learning out-come of students. The teacher, student, learning environment and parents all have their parts to play in achievement of academic excellence. This study is interested in identifying and comparing the learning style preferences of chemistry students associated with successful learning in public and private schools and also the relationship of these characteristics to their achievement in chemistry.

\subsection{Statement of the Problem}

Chemistry is a very important subject for students who want to pursue science and technology related disciplines at the tertiary level. Chemistry is the foundation of all environmental professions. Science students must learn and pass it before they can advance to higher institutions (Kolawole and Ilugbusi, 2007). Many have been denied admission due to inability to meet the basic entry requirements. In a good learning environment where the best teaching methods for chemistry and instructional materials have been utilized, successful chemistry learning may not still be achieved if the students lack necessary characteristics that are associated with successful chemistry learning. The performance of chemistry students in public examinations continue to fall below average. Hence, this study seeks to investigate the student characteristics (learning styles preferences) that are associated with successful chemistry learning in selected public and private schools in Lagos state. The most important student characteristics of concern to this research study are their learning style preferences.

\subsection{Purpose of the Study}

In view of the problem highlighted, this research work is undertaken to ascertain and compare which student characteristics (learning style preferences) will enhance successful learning of chemistry in the different school types.

\subsection{Research Questions}

The following research questions will guide the study:

1. Will there be any significant relationship between the learning style preferences of students in public schools and their performance in chemistry achievement test (CAT)?

2. Will there be any significant relationship between learning style preferences of students in private schools and their performance in chemistry achievement test?

3. Will learning style preferences of students significantly differ between public and private schools?

4. Will there be any significant gender difference in students' learning style preferences between the two school types?

\subsection{Research Hypotheses}

The following null hypotheses will guide the study:

1. There will be no significant relationship between the learning style preferences of students in public schools and their performance in CAT.

2. There will be no significant relationship between the learning style preferences of students in private schools and their performance in CAT.

3. There will be no significant difference in learning style preferences of students in public and private schools.

4. There will be no significant gender difference in students' learning style preferences between the two school types. 


\section{Methodology}

This study was limited to public and private senior secondary schools in Agege Local Government Area of Lagos State.

2.2 Research Design: Descriptive Survey Research Design was employed for this investigation. A Descriptive survey systematically describes the characteristic features of a given population. This design explains what has already been found to be in existence among the variables under investigation (Ilogu, 2008; Alade, 2007).

2.3 Population:The population for the study consisted of the entire senior secondary II (SS 2) students in public and private schools in Lagos State.

2.3 Sample and sampling technique: 200 senior secondary II students were chosen by stratified random sampling from selected public and private schools in Agege Local Government Area of Lagos State. Out of the twenty Local Government Areas in Lagos, Agege Local Government was chosen through a hat and draw method. The public and private schools are already in different strata. Within Agege Local Government, three private and three public school were randomly chosen by hat and draw method. Within each school type, disproportionate method (in the ratio of $60 \%$ private to $40 \%$ public) was used to pick the subjects. This is based on the fact that there are more private than public schools in Lagos state.

\subsection{Instrumentation:}

Research instruments used for this study are chemistry achievement test (CAT); Neil Flemming's VAK/VARK learning style Test (VLST). The part A of the VLST elicited information on student's age, school type, gender and parent's highest educational qualifications. Part B of the VSLT, consists of three subscales which include: three modalities- visual, auditory and kinaesthetics- by which human learning occurs. There are a total of thirty-six (36) statements in all. Each subscale consists of twelve (12) statements. Each statement will be scored on a 5-point scale with scores ranging from 1 to 5 . Total score for each subscale is summed up and written in the box provided. The subscale with the highest number of scores is the student's most preferred learning style. The VAK model was adapted for this research because of its ease of administration and simplicity. Flemming's Learning style test was also employed for this study because it is a tool for learning-tolearn (meta-learning). It increases the learner's self-awareness of his strengths and weaknesses so that he tries the various means of learning in order to choose the best one rather than stick to his preferred method. The chemistry achievement test (CAT) was made-up of 30-item multiple choice chemistry questions covering topics that students had been taught by their teachers. Topics were: Acids, Bases and Salts; Chemical Bonding, Particulate Nature of Matter; Properties of atomic particles; Separation Techniques. Content validity was ensured by the use of the test blue print shown in Table 1 .

Table1: Test Blueprint for a 30-item Chemistry Achievement Test

\begin{tabular}{|l|l|l|l|l|}
\hline Behaviour/Content Area & Knowledge & Comprehension & Application & \\
\hline Acids, Bases, Salts. 30\% & 4 & 3 & 2 & \\
\hline Separation Techniques. 30\% & 4 & 4 & 1 & 9 \\
\hline Properties of Atomic Particles. 20\% & 2 & 2 & 2 & 9 \\
\hline Particulate Nature of Matter. 20\% & 2 & 2 & 2 & 6 \\
\hline Total 100\% & 12 & 11 & 7 & 6 \\
\hline
\end{tabular}

The psychometric properties of the instruments were determined by subjecting them to scrutiny by educational measurement and evaluation experts for validation to ensure content and face validity. Pilot study was carried out to determine the reliability of the instruments. This was done in Ifako-Ijaiye Local Government because it had similar characteristics as the area under study. The pilot study was carried out on 30 chemistry students. Necessary amendments were made. After two weeks the same instruments were administered on the same respondents. The reliability coefficient of the test was computed using the two sets of scores obtained from the respondents. A reliability coefficient of 0.66 (for CAT) and the adapted VAK $r=0.70$ was obtained at 0.05 level of significance. Thus, the instruments were considered validated and reliable for use in this study.

Administration: The chemistry teachers in the sampled schools assisted the researcher in the administration of the research instruments. The students were told that the purpose of the questionnaires was to help them to ascertain how best they learn and improve their performance generally and specifically in the study of chemistry. They were also assured that their responses would be treated as confidential. 


\section{Data Analysis}

Chi-square statistics was used to analyse the collected data. Chi-square statistics was used because the researcher did frequency counts and put the subjects and their responses in categories. Those who were categorized as having passed the CAT scored 50\% and above. Scores below 50\% were categorized as failed.

\section{Discussion Of Results}

Table 2: Scores in "CAT", "School type" and "Learning Style Preferences"

\begin{tabular}{|c|c|c|c|c|c|c|c|c|c|}
\hline \multicolumn{5}{|c|}{ PUBLIC SCHOOL } & \multicolumn{5}{|c|}{ PRIVATE SCHOOL } \\
\hline $\begin{array}{l}\text { SCO } \\
\text { RE } \\
\text { IN } \\
\text { CAT }\end{array}$ & $\begin{array}{l}\text { VISU } \\
\mathrm{AL}\end{array}$ & $\begin{array}{l}\text { AUDI } \\
\text { TORY }\end{array}$ & $\begin{array}{l}\text { KINAEST } \\
\text { ETICS }\end{array}$ & TOTAL & $\begin{array}{l}\text { SCO } \\
\text { RE } \\
\text { IN } \\
\text { CAT }\end{array}$ & $\begin{array}{l}\text { VISU } \\
\text { AL }\end{array}$ & $\begin{array}{l}\text { AUDIT } \\
\text { ORY }\end{array}$ & $\begin{array}{l}\text { KINAESTE } \\
\text { TICS }\end{array}$ & $\begin{array}{l}\text { TOT } \\
\text { AL }\end{array}$ \\
\hline $\begin{array}{l}\text { PAS } \\
S\end{array}$ & 60 & 17 & 22 & 99 & $\begin{array}{l}\text { PAS } \\
\text { S }\end{array}$ & 32 & 26 & 20 & 78 \\
\hline FAIL & 13 & 02 & 06 & 21 & FAIL & 00 & 01 & 01 & 02 \\
\hline $\begin{array}{l}\text { TOT } \\
\text { AL }\end{array}$ & 73 & 19 & 28 & 120 & $\begin{array}{l}\text { TOT } \\
\text { AL }\end{array}$ & 32 & 27 & 21 & 80 \\
\hline
\end{tabular}

Table 2 above summarises the frequency of learning style preferences, school type and performance in CAT.

Table 2A: Chi-Square Analysis of Learning Style Preferences and Performance in Public schools

\begin{tabular}{|l|l|l|l|l|}
\hline $\mathrm{F}_{\mathrm{O}}$ & $\mathrm{Fe}$ & $(\mathrm{Fo}-\mathrm{Fe})$ & $(\mathrm{Fo}-\mathrm{Fe}) 2$ & $\left(\mathrm{~F}_{\mathrm{O}}-\mathrm{Fe}\right) 2 / \mathrm{Fe}$ \\
\hline 60 & 36.5 & 23.5 & 552.25 & 15.13014 \\
13 & 7.908333 & 5.091667 & 25.92507 & 3.278196 \\
17 & 2.691667 & 14.30833 & 204.7284 & 76.06009 \\
2 & 0.316667 & 1.683333 & 2.833611 & 8.948246 \\
22 & 5.133333 & 16.86667 & 284.4844 & 55.41905 \\
6 & 1.4 & 4.6 & 21.16 & 15.11429 \\
\hline & & & & 173.95 \\
\hline
\end{tabular}

TABLE 2B: Chi-square Analysis of Learning Style preferences and Performance in Private schools

\begin{tabular}{|l|l|l|l|l|}
\hline $\mathrm{F}_{\mathrm{O}}$ & $\mathrm{Fe}$ & $(\mathrm{Fo}-\mathrm{Fe})$ & $(\mathrm{Fo}-\mathrm{Fe}) 2$ & $\left(\mathrm{~F}_{\mathrm{O}}-\mathrm{Fe}\right) 2 / \mathrm{Fe}$ \\
\hline 32 & 12.8 & 19.2 & 368.64 & 28.8 \\
\hline 0 & 0.0 & 0.0 & 0.0 & 0 \\
\hline 26 & 8.775 & 17.225 & 296.7006 & 33.81204 \\
\hline 1 & 0.3375 & 0.6625 & 0.438906 & 1.300463 \\
\hline 20 & 5.25 & 14.75 & 217.5625 & 41.44048 \\
\hline 1 & 0.2625 & 0.7375 & 0.543906 & 2.072024 \\
\hline & & & & $\mathbf{1 0 7 . 4 2 5}$ \\
\hline
\end{tabular}

\section{Hypothesis 1}

There is no significant influence of learning style preferences of students in the public school on their performance in the chemistry achievement test (CAT).

This hypothesis was tested using the $\mathrm{x} 2$ square statistics. The figures under column "O" are the observed frequencies while those under "E" are the expected frequencies. Table 2A above shows the chi-square statistical analysis of learning style preferences and students' performance in CAT in the public schools. The calculated chi-square value is 173.95 . It is greater than the critical (table) chi-square value of 5.99 with 2 degrees of freedom at 0.05 level of significance. The null hypothesis which states that there is no significant influence of learning style preferences on the students' performance in CAT is rejected. This implies that students' choice of learning style did affect their performance in chemistry achievement score in the public school.

\section{Hypothesis 2}

There is no significant influence of learning style preferences of students in the private schools on their performance in CAT. Table 2B, above shows a calculated chi-square value of 107.425 which is greater than the critical value of 5.99 given 2 degrees of freedom at 0.05 level of significance. Hence, the null hypothesis is rejected meaning that learning style preferences influenced the students' performance in CAT. 


\section{Hypothesis 3}

There is no significant difference in the learning style preferences of students between public and private schools.

Table 3A shows the distribution of learning style preferences between public and private while table 3B shows the chi-square analysis. From table 3B, the computed chi-square value is 277.69 while the critical value is 5.99 given two degrees of freedom at 0.05 level of significance. The null hypothesis is rejected because the calculated value is higher than the table value. This means that a significant difference exits between the learning styles preferences of students in public and private schools.

TABLE 3A: Analysis by "School type" and "Learning Style Preferences"

\begin{tabular}{|l|l|l|l|l|}
\hline & LEARNING STYLE PREFERENCES & \\
\hline $\begin{array}{l}\text { SCHOOL } \\
\text { TYPE }\end{array}$ & VISUAL & AUDITORY & KINAESTETIC & TOTAL \\
\hline PUBLIC & 74 & 19 & 27 & 120 \\
\hline PRIVATE & 31 & 28 & 21 & 080 \\
\hline TOTAL & 105 & 47 & 48 & 200 \\
\hline
\end{tabular}

TABLE 3B: Chi-Square Analysis of "Learning Style Preferences" and "School type"

\begin{tabular}{|l|l|l|l|l|}
\hline$F_{O}$ & $F e$ & $(F o-F e)$ & $(F o-F e)^{2}$ & $\left(F_{O}-F e\right)^{2} / F e$ \\
\hline 74 & 38.85 & 35.15 & $1,235.52$ & 31.80 \\
\hline 31 & 16.28 & 14.73 & 216.83 & 13.32 \\
\hline 19 & 4.47 & 14.54 & 211.27 & 47.32 \\
\hline 28 & 6.58 & 21.42 & 458.82 & 69.73 \\
\hline 27 & 6.48 & 20.52 & 421.07 & 64.98 \\
\hline 21 & 5.04 & 15.96 & 254.72 & 50.54 \\
\hline & & & & 277.69 \\
\hline
\end{tabular}

TABLE 4A: Analysis by "Gender" and "Learning Style Preferences"

\begin{tabular}{|l|l|l|l|l|}
\hline & LEARNING STYLE PREFERENCES & \\
\hline GENDER & VISUAL & AUDITORY & KINAESTETIC & TOTAL \\
\hline MALE & 50 & 26 & 24 & 100 \\
\hline FEMALE & 55 & 21 & 24 & 100 \\
\hline TOTAL & 105 & 47 & 48 & 200 \\
\hline
\end{tabular}

TABLE 4B: Chi-Square Analysis of Gender and Learning Style Preferences

\begin{tabular}{|l|l|l|l|l|}
\hline $\mathrm{F}_{0}$ & $\mathrm{Fe}$ & (Fo-Fe) & $(\mathrm{Fo}-\mathrm{Fe}) 2$ & $\left(\mathrm{~F}_{0}-\mathrm{Fe}\right) 2 / \mathrm{Fe}$ \\
\hline 50 & 26.25 & 23.75 & 564.06 & 21.49 \\
\hline 55 & 28.88 & 26.12 & 682.25 & 23.62 \\
\hline 26 & 6.11 & 19.89 & 395.61 & 64.75 \\
\hline 21 & 4.94 & 16.06 & 257.92 & 52.21 \\
\hline 24 & 5.76 & 18.24 & 332.70 & 57.76 \\
\hline 24 & 5.76 & 18.24 & 332.70 & 57.76 \\
\hline & & & & $\mathbf{2 7 7 . 5 9 1 4}$ \\
\hline
\end{tabular}

\section{Hypothesis 4}

There will be no significant gender difference in the learning style preference of students in both school types. Table 4A shows the distribution of learning style preferences between male and female students in both school types, while Table 4B displays the chi-square analysis of hypothesis 4. Chi-square calculated is 277.59 which is greater than the critical value of 5.99 given 2 degrees of freedom at 0.05 level of significance. Since the calculated value is greater than the table value, we reject the null hypothesis. This means that a significant gender difference exits in the learning style preferences of male and female students within the sampled population.

\section{Discussion}

The result of the study showed that learning style preferences chosen by the students whether in the private or public school went a long way to determine their performances in chemistry achievement test. The findings of hypothesis one and two are in conformity with Ogundokun (2004) who pointed out that learning styles, school environment and test anxiety jointly predicted learning outcome of students in Iseyin Local Government Area of Osun State, Nigeria. 
Hypothesis three stated that there is no significant difference in the learning style preference between the public and private schools. The results showed that there is significant difference in the learning style preferences between the two school types. Majority of the students in public school preferred the visual learning style to auditory and kinaesthetic. This could be due to the fact that the population of the students enrolled in the public schools often outnumber the laboratory facilities which favour kinaesthetic style of learning. This is in consonance with findings of the Education Sector Support Programme in Nigeria (ESSIPN, 2011). Oftentimes, students in public schools do not perform practical work until it is time to write an external examination. Hence, their teachers resort to using visual learning aids which supports visual learning style in their students.

Hypothesis four stated that there is no gender difference in learning style preferences among the students showed that a significant difference exits between the male and female participants. Majority of the female students preferred visual learning to auditory and kinaesthetic styles of learning. Their preference could be due to erroneous cultural beliefs that handling of dangerous chemicals and laboratory equipment was better done by their male counterparts. This is in agreement with Sara (2010) who studied the effects of learning styles on career preferences of Senior Secondary school students in Jigawa State, Nigeria. His investigation revealed that the male were more field-independent while the female were field dependent learners. Field-dependent student according to him are those students who think rationally in problem solving while field independent students think irrationally when confronted with a problem.

\section{Recommendations}

On the basis of the findings the following recommendations were made:

In order to help students with the life-long process of learning it is important that a student understands his or her own preferred learning style. If you do not know the best way to process information according to your learning style, you may not be able to retain information as well as you should. Learning style has got nothing to do with level of intelligence. There is no right or wrong way of learning. If a student understands how best he learns and processes information, then learning can be done in the most conducive way.

Visual learners process information best when the teacher uses visual aids like overhead projectors, pictures, film, maps and hand-outs. Auditory learners understand, process and retain information when they listen to lectures or presentations and partake in group discussions. Using pod-casts, audio lectures and webinars benefit auditory learners. Kinaesthetic learners retain information most when they touch and do things like engaging in laboratory practical and field work.

Teachers should have a basic knowledge of various characteristic behaviours of students adopting different learning styles.

Teachers should use and adopt different teaching styles and instructional strategies so as to match their teaching with the students learning styles. Experiential teaching, inquiry method, cooperative learning and dramatization could be adopted by the chemistry teacher.

Teachers should use a wide variety of teaching styles to accommodate students of different learning styles in their classroom. This will not only improve teaching and learning but Increase the rate at which chemistry students retain acquired knowledge.

\section{Conclusion}

This has been an attempt to compare the learning style preferences of chemistry students in selected public and private schools in Lagos metropolis. In line with the results of the study, the following conclusions can be drawn:

A student's choice of learning style affects his performance in that subject.

Visual learning style was the most preferred learning style among the students in both public and private school.

There was gender difference in the learning style preference among the students. The female students preferred the visual learning style. This may be due to their cultural beliefs to avoid dangerous chemistry practical.

Teachers can utilize the knowledge of their students' learning style preferences to improve teaching and also plan remedial classes for weak chemistry students. An effective teacher is one whose teaching style aligns with the students' varied learning style preferences. It would be interesting to investigate whether learning styles vary with the different subject areas the students are taught. More research needs to be done on the influence of culture on students' learning styles.

\section{References}

[1] Adeyemi, T.O. (2011). A Comparative Study of Students' Academic Performance in Public Examinations in Secondary Schools in Ondo and Ekiti States, Nigeria.Current Research Journal of Economic Theory 3(2): 36-42, 2011 ISSN

[2] Adesoji, F.A. and Ibraheem, T.L. (2009) (Effects of student team-achievement divisions strategy and mathematics knowledge on learning outcome in chemical kinetics. Journal of International Social Research.Vol 2/6 winter 2009 
[3] Alade, O.M. (2007). Teacher Attitude to Inspectors and Inspection: Quality Control. International Journal of Educational Research.ISSN1595-8485.Vol3 no2.pp203-217. Lagos: Vita Educational Books.

[4] Al-Methen, A.E. and W.J. Wilkinson, 1992.Perceived causes of failure among secondary school students.Manchester University Press, November, Res.Edu., 48:26-35.

[5] Apanpa, O.S and Ogunbiyi, O. (2012). Learning and Teaching styles in Language, Science and Technology in Nigeria.British Journal of Arts and Social Sciences ISSN: 2046-9578, Vol.5 No.2 (2012) CBritishJournal Publishing, Inc. 2012 http://www.bjournal.co.uk/BJASS.aspx

[6] Berg, C.A.R. (2005). Factors related to observed attitude change toward learning chemistry among university students. Chemistry Education and Practice. 2005, 6 (1) $1-18$.

[7] Dunn, R., \& Dunn, K. (1992). Teaching secondary students through their individual learning styles: Practical approaches

[8] Dunn, R., \& Dunn, K. (1992). Teaching secondary students through their individual learning styles: Practical approaches for grades 7-12. Boston: Allyn and Bacon.

[9] Felder, $\quad$ Richard. (1993). "Learning Styles".North University.http://www4.ncsu.edu/unity/lockers/users/f/felder/public/papers/Is1988pdf Retrieved 01/11/12.

[10] Fleming, N.D. (2001). Teaching and Learning Styles: VARK Strategies. Honolulu Community College

[11] Gardner, H. (1993). Frames of mind: The theory of multiple intelligences $/ 10^{\text {th }}$ Anniversary Edition. New York: Basic Books.

[12] Gremli, J. (1996). Tuned in to learning styles. Music Educators Journal,83, 24-27.

[13] Intime (2001). Knowledge of students' Characteristics: Definition and Checklist. Integrating New technologies into the Methods of Education. Retrieved on 27 March 2013 from: http://www.intime.uni.edu/generalinfo/privacy.html

[14] Ilogu, G.C. (2008). Educational Research and Evaluation: A Companion for Students. Lagos: Wealthsmith Books.

[15] Kolawole, E.B, Ilugbusi, A.A. (2007). Cognitive entry grade as predictors of students academic performance in mathematics in Nigeria universities. Medwell J., 2(3): 322-326.

[16] Kolawole,E.B, Oginni,O.I and Fayomi, E.O (2011). An Ordinary Level as Predictors of Students' Academic Performance in Chemistry in Nigerian Universities.Educational Research and Reviews vol. 6(14), pp 824-827. ISSN 1990-3839 http://www.academicjournals.org/ERR

[17] Ogundokun, M.O. (2004).Learning style, school environment and test anxiety as correlates of learning outcomes among secondary school students. IFE PsychologIA. ISSN: 1117-1421 www.ajol.info/

[18] Paulson, D.R. (1999). Active Learning and Cooperative Learning in the Organic Chemistry Lecture Class,J. Chem Ed. 1999, 76, $1136-1140$

[19] Sara, S.S. (2010). Effects of learning styles on career preferences of senior secondary school students in Jigawa state, Nigeria.Edo journal of counselling, vol. 3, no1.

[20] Soloman, Barbara A.; Felder, Richard M. (2003)."Index of learning styles questionnaire". North Carolina State University. http://www.engr.ncsu.edu/learningstyles/ilsweb.html .Retrieved 1 November 2012

[21] Spoon J.C., \& Schell, J.W. (1998). Aligning student learning styles with instructor teaching styles.Journal of Industrial Teacher \begin{tabular}{llllll} 
Education, & 35, & $41-56$. & Retrieved & 12 & January \\
\hline
\end{tabular} "http://en.wikipedia.org/w/index.php?title=Learning_styles\&oldid=549409489"

[22] Tooley, J. Dixon, P. and Olaniyan, O. (2005) Private and public schooling in low-income areas of Lagos State, Nigeria: A census and comparative survey, in International Journal of Educational Research 43(2005), pp.125-146.

[23] Yeung, A., Read, J., and Schmid, S. (2005). Students' learning styles and academic performance in first year chemistry.The University of Sydney :UniServe science Blended Learning Symposium Proceedings. 